\title{
REMARKS: PANEL OF CHANCELLORS
}

\author{
James Moeser \\ Chancellor \\ University of Nebraska-Lincoln
}

Mike Crow's call for a niche strategy is not unlike what we have been advocating at the University of Nebraska. We are now in the second year of a major reallocation of the state-aided budget in order to redirect resources toward major academic priorities. We are committed to a strategy of building excellence upon existing strengths. However, we have come to the point where I do not believe it is possible to create exponential change only with reallocation or redirection of existing resources.

I have told our faculty, it is time for a bold new initiative. Fortunately, I believe that we should be able to draw on some new sources of revenue to create new levels of excellence without eroding our core programs. I have accepted as the responsibility of my administration to identify new streams of resources to create a new fund for investment to build excellence in the future. We will put some real money on the table.

In turn, I have asked the faculty to provide the direction in establishing our major academic priorities, suggesting that we turn the question of the University's future into a research problem and assigning this to a team of faculty researchers. This project will require a candid assessment of the status and quality of current programs, an assessment of where special opportunities might lie, an analysis of major problems affecting the world or our nation that this University is well positioned to solve, and the vision and creativity to imagine what might be possible with enhanced resources or a reconfiguration of existing resources.

To help us chart the course for the future, I have appointed a select faculty task force to be chaired by the Senior Vice Chancellor to be the research team that will help design the university of the future. We are calling this committee the Future Nebraska Task Force. It will consider these questions:

- What are our areas of greatest strength or potential for future development where significant new investment would move a program or a constellation of programs up to a new level of excellence and reputation?

- What are the great issues, the great problems affecting the world and the nation that need to be solved?

- What problems or opportunities are unique to Nebraska or the Great Plains that should shape our agenda? 
- Which of those areas should we claim as ours?

- What are the unique resources of this University in attacking those problems?

- What are the imperatives of our land-grant mission that define our research agenda?

Our premise is that excellence is best built upon existing strengths or in responding to special opportunities. This strategy may lead to greater focus in selected areas. We must temper this approach with several constraints. First, we must maintain an internal balance between and among the major segments of learning and research. We cannot become a technological institute. We must balance the hard sciences with the humanities, the arts, and the social sciences. And we cannot become so focused that we abandon our comprehensive mission.

Moreover, we must attain greater focus in our research mission without distorting the balance of our multiple missions. We must remain on course with regard to the renewed emphasis on teaching and learning, on excellence in our undergraduate programs, and we must remain faithful to our land-grant mission of engagement and outreach to the people of the state and the nation.

I have been intentionally imprecise with regard to the plan of operation for this task force. Like any good research project, the methodology and procedure ought to be developed by the research team, not handed down in advance. My only requirement is that the plan must be designed to create a strategy to move Nebraska forward in research and graduate studies in the next five years.

This effort will need to be coupled with intensified strategic planning within the colleges. In every college, we need to be asking the same questions I posed above. Ultimately, it will be proposals from the colleges, or from interdisciplinary consortia that cross college lines, that will determine where the investments are made.

These new resources are made possible through a variety of sources, the most significant being private philanthropy. We have made some enormous strides in private support in the last few months. In May, we announced what was then the largest gift in the history of the University, a gift of $\$ 32.2$ million from Ed and Carole McVaney of Denver, Colorado, to create the J. D. Edwards Honors Program in Computer Science and Management. This gift is not an endowment, but will build the Esther M. Kauffman Residential Learning Center that will house the students in the program, special classrooms and computer labs, and living quarters for visiting faculty and a resident faculty principal. The remainder of the gift operates this new honors program for five years, providing full scholarships for students and support for faculty. The terms of the gift are such that, if we are successful in building the program we have envisioned, the McVaneys will continue to support the program at an annual cost of approximately $\$ 4.5$ million per year. It is an open-ended, rolling commitment, with an assurance to the University that support will always be in place for five years in the future. 
More recently, the University of Nebraska-Lincoln received a bequest of approximately $\$ 110$ Million from the estate of Donald and Mildred Topp Othmer. This estate establishes an endowment which will fund a chair in chemical engineering and allow us to realize two of the stated objectives of Campaign Nebraska-new physical facilities for chemical engineering and expansion of Love Library.

While the first impact of this endowment may be seen in brick and mortar, the long-term impact on the campus will be on academic quality. The clear intent of this gift is to augment and enhance support from the state. It must not be used to supplant or replace the state's responsibility of basic support for our core missions. Rather, it will be reserved to create or enhance excellence in academic programs. Income from the Othmer endowment will be one of the principal sources of funding for the Future Nebraska Task Force process I just described.

In addition, I believe we can leverage new contributions as a result of the Othmer gift. I have challenged our deans to create within the next five years 24 new \$1 million endowed university distinguished professorships by designating a portion of the income from the Othmer Endowment to match new contributions one-to-one; for every new commitment of a half-million, we'll dedicate the other half, thus doubling the effect of every new contribution. These positions will be filled by competitive national searches subject to our own rigorous internal review processes.

Through this combination of strategies, we can lay the foundation for excellence in the 21st Century. Quite candidly, part of my strategy is to energize and excite our faculty to use their creativity to help envision the university of the future. The process of reallocating and shifting resources, while necessary, has been debilitating and demoralizing. For every winner, there are several losers. With some critical new resources, and with a continued run of good luck in the form of stable support from the state (alas, this is not a given in Nebraska), I believe it should be possible for us to engage in a process that is not about dividing up existing resources to make short-term gains, but about new investments for the future.

Without losing sight of our comprehensive mission as the primary research and land-grant university for Nebraska, I believe it should be possible for us to position the university to have research and graduate programs that are among the finest in the nation or the world, if we have the discipline to use our resources wisely, targeting them to specific areas of strength and focus. And I use the word discipline advisedly. Already, since announcing the formation of the task force, I have been besieged with requests that I include excellence in teaching, or in outreach and service as worthy targets for investment. And politicians have already begun suggesting that these funds might allow for reductions in tuition or tax support for the university.

We must maintain our focus and our discipline. I intend to hold a firm position that these investments will be in research and graduate education, and not across the board there, but in targeted areas of excellence. I believe that the future of the University hangs in the balance-either a supermarket of average and adequate programs, or an 
institution with comprehensive offerings at the undergraduate level and some select areas of distinction in graduate education and research.

While no two institutions will follow the same road map to their destination, I am convinced that the universities of mid-America have much in common. I believe this is the right strategy for Nebraska, and I suspect, that our sister institutions will follow a similar path. I have told our faculty that I believe the greatest days of the University of Nebraska lie ahead of it. I hope the same is true for Missouri and Kansas as well. 